\title{
An innovation adoption model of licensing-in for US start-ups
}

\author{
Bernadette Power ${ }^{1, *} \bullet$ Gavin C. Reid ${ }^{2,3}$ \\ ${ }^{1}$ University College Cork, Ireland \\ ${ }^{2}$ Cambridge Judge Business School, University of Cambridge, UK \\ ${ }^{3}$ School of Economics and Finance, University of St. Andrews, UK
}

Received: 10 December 2020

Revised: 19 May 2021

Accepted: 1 June 2021

\begin{abstract}
Using the Kauffman panel dataset of US start-ups, we analyse the key determinants of licensing-in adoption. Licensing-in entails an intellectual property contract between the licensor (e.g. upstream established firm) and licensee (e.g. downstream start-up) aiming to bring an innovation to market rapidly. Assuming maximizing of the owner's managerial utility in the start-up years, we explain licensing-in adoption through firm characteristics like size, R\&D and capital structure, as well as other IP types, and controls for year and regional fixed effects, using panel probit estimation with adjustments for sample selection bias and endogeneity. We find key determinants of licensing-in to be owners' equity, product (rather than service) sales and R\&D spend; and then comment on their policy implications for business incubation.
\end{abstract}

Keywords: Licensing-in; US start-ups; IP adoption

JEL Classification Codes: M2, L2, L5, O32, O34

\section{Introduction}

This paper is concerned with enterprise-based knowledge inflows in the form of licensing-in, also called 'in-licensing'. Its focus is the determinants of licensing-in activity by US start-ups. Licensing-in is a type of intellectual property (IP) (Lemley 1999). It typically involves a formal contract, (Anand and Khanna 2000), that puts the responsibility on a small start-up (the licensee) to get an innovative product to market rapidly, in exchange for which an upstream established firm (the licensor) provides the necessary resources, financial and technical, to accelerate product development and reduce the time to product launch (Razgaitis 2003). The current rise of research interest in licensing-in is part of collective disillusion with 'closed innovation' practices and an emerging appetite for 'open innovation', driven by inflows and outflows of knowledge within and between firms, all aiming to generate, and to sell, innovation (Chesbrough 2003; Pereira et al. 2015; Santoro et al. 2018).

Extant research on licensing-in emphasizes its potential benefits. For example, it can

\footnotetext{
*Corresponding author. E-mail: b.power@ucc.ie.
}

Citation: Power, B., and Reid, G. C. (2021) An innovation adoption model of licensing-in for US start-ups, Economics and Business Letters, 10(4), 369-382.

DOI: 10.17811/ebl.10.4.2021.369-382 
accelerate innovation, contribute to new product development at lowered cost and risk, diversify a firm's portfolio, and prevent technological obsolescence (Authane-Gima 2003; Laursen et al. 2010; Belingheri and Leone 2017). Studies show licensing-in to have a positive impact on financial performance, innovation, and growth (Hung and Chou 2013; Parida et al. 2012; Pereira et al. 2015). It can also help start-ups to overcome limitations of scale, like undercapacity, by generating indigenous R\&D (Tsai and Chang 2008; Belingheri and Leone 2017).

As licensing-in can transform the development of start-ups, it is to the advantage of researchers, practitioners, and policymakers to understand what factors drive licensing-in adoption. This is the research gap that this article aims to fill. Recent research around licensingin offers insight into its potential determinants. Consistent with the absorptive capacity approach of Cohen and Levinthal (1990), more recent research suggests that higher internal R\&D capabilities are positively linked to licensing-in activity by large firms (Cassiman and Veguelers 2006; Tsai and Chang 2008; Wang and Li-Ying 2014), including international licensing-in, Dohse et al. (2019). However, for the specific case of licensing-in within small start-ups, there has been little evidence to corroborate this. Both Sikimic et al. (2015) and Pereira et al. (2015) confirm the synergies between licensing-in and licensing-out activities for large firms, but this has not been explored for small start-ups in the context of licensing-in new technologies. Turning to industry characteristics, increased technological turbulence, high levels of competition, and manufacturing or supplier-dominated industries have been found to be linked to higher levels of licensing-in (van de Vrande et al. 2009; Zahra et al. 2005). While research finds that large firms that produce products (as opposed to services) are more likely to register or use intellectual property (Gallié and Legros 2012; Chen and Wu 2020), few works examine the impact of this factor on the decision to license-in within start-ups. However, at the firm-level, there is a general finding that strategic choices (e.g. on the level of risk, breadth of product lines, and speed-to market) all affirm the utility of licensing-in (Authane-Gima 2003), as do the scarcity of resources, both human and financial. Such resources have been shown to enhance open innovation (Dreschler and Natter 2012), particularly for inward licensing (Dohse et al. 2019; Jang et al. 2019), including in international settings.

While these findings are laudable, large gaps remain in empirical studies concerning specifically the licensing-in adoption decision. For example, van de Vrande et al. (2009) looked at open innovation in a sample of Dutch firms, but explicitly excluded micro-enterprises (less than ten employees) which are at the heart of our own work on start-ups. Further, we evade the lack of formalism of works like van de Vrande et al. (2009) which did not use econometric methods, or formal model building. Our article builds on such early works in a more targeted way and aims to add value in a research sense by examining the impact of multiple determinants of licensing-in using an advanced econometric analysis of a large longitudinal sample of US start-ups.

The advantages of licensing-in to a start-up (viz its accelerated development stage, and its competitive advantage over incumbent rivals) extends from academic research to practice and policy. Schafer (2002) was one of the first business practitioners to identify licensing-in specifically as a US business model and referred to it as being possibly a fad because 'business models go in and out of fashion'. That has proven pessimistic. While slow to start, licensing-in has become highly favoured by investors, mainly because experience has shown that it accelerates company development, USITC (2020). This is because with licensing-in there is an enhanced route to an economic payoff.

To explain, with standard venture capital intervention in promising start-ups the payoff is often considerably delayed to when the firm goes public, in the hope then of providing a high return on the original investment, Reid (1998). By contrast, licensing-in appeals to ambitious owner managers, who aim for a more favourable economic existence than trying to breathe life 
into failed products of giant companies. Rather, this type of owner manager wants to see their start-up being a quick-actioning tool for innovation, rather than an alternative tool to innovation.

By their nature, start-up owner managers are attracted to processes that enable risk attenuation and cost reduction that can be achieved by licensing-in, Blank and Dorf (2020). To acquire these benefits, the licensee needs to look at the track record of the licensor and gauge its reliability and capacity e.g. in terms of financial and technical support. In turn, the licensor might wish to agree a flexible royalty arrangement that allows for trigger events like an increase in licensee costs (on the downside), or an achievable rise in product price (on the upside). If the licensee is able to get technological leverage from its imported innovations, enabling it to develop independently new IP, it might want to substantiate a proprietorial right over such derivative work, and in this case, the licensor might want to receive a 'grant-back' in recognition of earlier support for the licensee, Laursen et al. (2017).

In looking at broader implications of the adoption pattern of licensing-in, one must bear in mind that the international dimension can be important. To illustrate, while PR China already has a strong technological base, there is clear evidence, see Wang and Li-Ying (2014), that indigenous firms which engage in international licensing-in enjoy positive spill-over performance benefits from this in terms of their best use of indigenous licensing-in. This insight is potentially relevant to other international settings, including of course the USA.

For US start-ups, Belingheri and Leone (2017) find that their IP strategies to be more flexible than incumbent firms. This is especially true of licensing-in from external companies, which enables immediate access to viable external technologies at the start of their business life cycle, a phenomenon they call 'walking into the room with IP'.

\section{Methods}

Our modelling approach assumes a managerial model of the start-up, in which the owner manager maximises a utility (U) function whose arguments include intellectual property (IP) types, and further economic, financial, and organizational control variables. This utility function is denoted $\mathrm{U}_{\mathrm{ij}}($.) where the index $i$ denotes an IP type like licensing-in and the index $j$ denotes a specific start-up. To create an estimable econometric model of the start-up, we adopt the random utility approach of Hensher and Johnson (2018), specified as:

$$
\mathrm{U}_{\mathrm{ij}}=\mathrm{A}_{\mathrm{ij}}+\mu_{\mathrm{ij}}
$$

where the $\mathrm{A}_{\mathrm{ij}}$ in equation (1) are deterministic and the $\mu_{\mathrm{ij}}$ are random variables which are independently and identically distributed over IP types (indexed $i$ ) and start-ups (indexed $j$ ). We represent the choice set as $\left\{\mathrm{C}_{\mathrm{j}}\right\}$, which here reduces to the simple choice between 'adopting licensing-in' and 'not adopting licensing-in'. We represent the probability that the $\mathrm{j}$ 'th start-up adopts licensing-in, the i'th IP type, as follows:

$$
P_{j}(i)=\operatorname{Prob}\left(U_{i j}>U_{k j}\right)=\operatorname{Prob}\left(A_{i j}+\mu_{i j}>A_{k j}+\mu_{k j}\right)=\operatorname{Prob}\left(\mu_{k j}-\mu_{i j}<A_{i j}-A_{k j}\right)
$$

where inequalities in equation (2) hold for all $(i, k)$ in the choice set for the $j$ 'th start-up.

Assuming the $\mathrm{A}_{\mathrm{ij}}$ and $\mathrm{A}_{\mathrm{kj}}$ have linear parameterisations, our estimable model is a binary probit with $\mathrm{P}_{\mathrm{j}}(\mathrm{i}=1)=\Phi\left(\boldsymbol{\beta}^{\prime} \mathbf{x}\right)$ for the unit standard normal cumulative density function $\Phi$, parameter vector $\boldsymbol{\beta}$ and data vector $\mathbf{x}$, Greene (2020, Part IV). On the above basis, our probit took the implemented form of equation (3) below:

$$
\begin{gathered}
\text { Prob (Adoption of Licensing-in) } \equiv \mathrm{y}=\mathrm{F} \text { (Start-up Characteristics, Other IP types, } \\
\text { Controls, Random Variables) }
\end{gathered}
$$

In implementing the model given in equation (3) we used panel binary probit estimation, with $\mathrm{y}=1$ if the start-up had adopted licensing-in during a particular year, and $=0$ if not. In equation (3) the 'Start-up Characteristics' included employee size, incorporation, ownership, financial 
structure (e.g. debt, equity). 'Other IP types' included patents, licensing-out, copyrights, trademarks etc. 'Controls' included years, sectors, and the knowledge intensity of services or the high technology nature of manufacturing firms. The 'Random Variables' involved the composition of the error term $\mu_{\mathrm{ij}}$ with various other error terms arising from our test procedures. Brief definitions and associated descriptive statistics of variables are provided in Section 3 along with a brief justification for their inclusion.

Parameter estimates of $\boldsymbol{\beta}$ were computed using Stata ${ }^{\circledR}$ software for panel probits controlling, by year, region and sector, for fixed-effects and clustering the errors by firm $j$ (see Section 3 , Table 2, column 2). From these estimates, we derived marginal effects $(\partial y / \partial x)$ and elasticities (Ey/Ex), see Section 3, Table 2 (columns three and four). Gauss-Hermite quadrature was used to maximize the likelihood function, typically converging in four iterations. Our panel estimation was concluded by testing for endogeneity, see Hausman (1978), and sample selection bias, see Vella (1998).

\section{Data and descriptive statistics}

Our study uses the Kauffman Firm Survey, Robb and Reedy (2011), to explore the licensing-in activities of US firms for their first 8 years of operation from 2004 to 2011 . In the base year of 2004, 4,928 surveys were completed, representing a 43\% response rate when sampling weights are applied (Ballou et al. 2008). These firms were then tracked annually, with respondent numbers falling year-by-year due to attrition, refusals, change of contact and business exits. Data were collected by a self-administered web survey, backed up by Computer-Assisted Telephone Interviewing (CATI).

We used a total sample of 22,264 observations. This sample started with 4,866 firms founded in 2004, which were tracked until the seventh follow-up, at which point there were 2,046 firms remaining. These observations covered all NAICS sectors from 11 to 92 . The average size of start-up's by employees in our sample was 2.9 (st. dev. =6.1). Our Kauffman Firm Survey data are known to be a good reflection, over many dimensions, of the population of start-ups in the USA, see Farhat et al. (2018).

Brief definitions of all variables are contained in Table 1, and a fuller explanation of these definitions is provided in the supplementary material (Appendix A). Our dependent variable, Licensing-in, is explained by typical determinants some which are referred to in Section 2 above. Firm characteristics include Size, as open innovation tends to more driven by larger than smaller firms (van de Vrande et al. 2009; Licthenthaler 2008; Dohse et al. 2019). Measures capturing ownership status include Incorporated and Team, similar to Zahra et al. (2005) and Dohse et al. (2019), and measures of the resources of the firms include assets (Purchased), financial assets (Equity, Debt) and human capital $(P h D)$, following Cassiman and Veugelers (2006) who argue that a lack of resources positively influence the licensing-in of IP. Other works supporting a positive effect for human capital include Dohse et al. (2019). As indicated above, Gallié and Legros (2012), in investigating firm IP protection, find that industrial firms are more likely to use formal IP than service firms, and therefore include the product profile of the firms as one of their regressors. Most papers find a strong positive effect of internal R\&D on licensing-in or open innovation (Cassiman and Veugelers 2006; Hung and Tang 2008; Tsai and Chang 2008; Tsai and Wang 2007; Dohse et al. 2019; Wang and Li-Ying 2014; Lichtenthaler 2008). The technological regime of the start-up is captured in our paper by our High-tech variable and the knowledge intensity of services (Low/High Knowledge IS). They are included as controls in our estimation in a similar fashion to Spithoven et al. (2013). We are influenced by Hung and Tang (2008) who find that firms with higher technological capability are parsimonious with their resources and see licensing-in as a 'lean' alternative. While the complex interrelationships among different types of IP is discussed by Amara et al. (2008) and 
captured in recent studies such as Lee et al. (2017), this largely explores only the internal effect of licensing-in on licensing-out (Sikimic et al. 2016; Hu et al. 2015). By contrast, we go beyond this, and look at the impact of a more comprehensive range of IP types on the adoption of a specific IP type. In doing so, we also include four regional dummies to capture the influence of four broad census bureau regions in the USA (e.g. northeast, mid-west, south and west). We use sectoral, regional and year dummies to capture these diverse fixed effects in our panel estimation.

Table 1 gives a clear characterisation of our average start-up. The typical start-up is incorporated, sole owner-managed, and functions in rented premises or from home. It has about three employees and has a small amount of equity invested in the firm. It tends to be service based and is typically not high-tech. Start-ups more often rated themselves as using high (rather than low) knowledge intensive services businesses. Some owner managers had a PhD but the average count $(0.10)$ was less than one. About $20 \%$ of the start-ups spent money on R\&D. In terms of the range of IP types, copyrights were the type most commonly held, followed by trademarks and then patents. Licensing-in occurred for $6 \%$ of start-ups and licensing-out for $2 \%$ of start-ups.

Table 1. Definitions of Variables, Means and Standard Deviations.

\begin{tabular}{|c|c|c|c|}
\hline Variable & Definition & Mean & SD \\
\hline Size & A count of all FT and PT employees & 2.9 & 6.1 \\
\hline Debt & $\begin{array}{l}\text { Total owner and total business debt } \\
\text { (categorial) }\end{array}$ & 2.9 & 3.2 \\
\hline Team & $=1$ if more than one owner; $=0$ otherwise & 0.38 & 0.49 \\
\hline Purchased & $=1$ if purchased premises; $=0$ otherwise & 0.064 & 0.25 \\
\hline Incorporated & $=1$ if incorporated $;=0$ otherwise & 0.65 & 0.48 \\
\hline Equity & Total owner manager equity (categorial) & 2.15 & 2.80 \\
\hline Service & $\begin{array}{l}=1 \text { if a business sells a service } ;=0 \\
\text { otherwise }\end{array}$ & 0.86 & 0.35 \\
\hline Product & $\begin{array}{l}=1 \text { if a business sells a product } ;=0 \\
\text { otherwise }\end{array}$ & 0.49 & 0.50 \\
\hline$P h D$ & Count of owners with PhD degree & 0.10 & 0.36 \\
\hline$R \& D$ spend & $=1$ if spends money on $R \& D ;=0$ otherwise & 0.19 & 0.39 \\
\hline High-tech & $\begin{array}{l}=1 \text { if } 28 \text { Chemicals, } 35 \text { Industrial, } 36 \\
\text { Electrical, } 38 \text { Instruments; = } 0 \text { otherwise }\end{array}$ & 0.13 & 0.33 \\
\hline Patents & Count of patents & 0.17 & 2.00 \\
\hline Copyrights & Count of copyrights & 1.49 & 12.00 \\
\hline Trademarks & Count of trademarks & 0.28 & 1.46 \\
\hline Licensing-out & $\begin{array}{l}=1 \text { Licensing out any form of legal property } \\
\text { rights; }=0 \text { otherwise }\end{array}$ & 0.02 & 0.14 \\
\hline Licensing-in & $\begin{array}{l}=1 \text { Licensing in any form of legal property } \\
\text { rights; }=0 \text { otherwise }\end{array}$ & 0.06 & 0.23 \\
\hline Manufacturing & $=1$ if Manufacturing $;=0$ otherwise & 0.14 & 0.34 \\
\hline Construction & $=1$ Construction; $0=$ otherwise & 0.080 & 0.2187 \\
\hline Wholesale/Retail & $=1$ Wholesale and Retail; $0=$ otherwise & 0.14 & 0.35 \\
\hline Low Knowledge IS & $\begin{array}{l}=1 \text { Low Knowledge Intensive Services; }=0 \\
\text { otherwise }\end{array}$ & 0.24 & 0.43 \\
\hline High Knowledge IS & $\begin{array}{l}=1 \text { High Knowledge Intensive Services; }=0 \\
\text { otherwise }\end{array}$ & 0.38 & 0.49 \\
\hline
\end{tabular}


Table 2. Panel Probit ML Estimates

\begin{tabular}{|c|c|c|c|}
\hline Variables & $\begin{array}{r}\text { Parameters } \boldsymbol{\beta} \\
\text { (Standard error) }\end{array}$ & $\begin{array}{r}\text { Marginal effects dy/dx } \\
\text { (Standard error) }\end{array}$ & $\begin{array}{r}\mathbf{E y} / \mathbf{E x} \\
\text { Elasticities } \\
\end{array}$ \\
\hline \multirow[t]{2}{*}{ 1. Size } & $0.0118 * * *$ & $0.0002 * * *$ & 0.0974 \\
\hline & $(0.0041)$ & $(0.0001)$ & $(0.0342)$ \\
\hline \multirow[t]{2}{*}{ 2. Debt } & 0.0104 & 0.0001 & 0.0872 \\
\hline & $(0.0082)$ & $(0.0001)$ & $(0.0688)$ \\
\hline \multirow[t]{2}{*}{ 3. Team of Owners } & $0.1167 *$ & $0.0017 *$ & 0.1284 \\
\hline & $(0.0657)$ & $(0.0010)$ & $(0.0726)$ \\
\hline \multirow[t]{2}{*}{ 4. Purchased } & -0.1834 & $-0.0021 *$ & -0.0345 \\
\hline & $(0.1279)$ & $(0.0010)$ & $(0.0240)$ \\
\hline \multirow[t]{2}{*}{ 5. Incorporated } & 0.1011 & 0.0014 & 0.1894 \\
\hline & 0.0711 & $(0.0010)$ & $(0.1334)$ \\
\hline \multirow[t]{2}{*}{ 6. Owners' Equity } & $0.0310 * * *$ & $0.0004 * * *$ & 0.1915 \\
\hline & $(0.0084)$ & $(0.0001)$ & $(0.0525)$ \\
\hline \multirow[t]{2}{*}{ 7. Service } & 0.0013 & 0.0000 & 0.0031 \\
\hline & $(0.0811)$ & $(0.0011)$ & $(0.2033)$ \\
\hline \multirow{2}{*}{ 8. Product } & $0.3664 * * *$ & $0.0055^{* * *}$ & 0.5072 \\
\hline & $(0.0588)$ & $(0.0012)$ & $(0.0830)$ \\
\hline \multirow{2}{*}{ 9. $P h D$} & 0.0972 & 0.0014 & 0.0270 \\
\hline & $(0.0688)$ & $(0.0010)$ & $(0.0192)$ \\
\hline \multirow[t]{2}{*}{ 10. Spend on $R \& D$} & $0.3072 * * *$ & $0.0057 * * *$ & 0.1614 \\
\hline & $(0.0583)$ & $(0.0016)$ & $(0.0309)$ \\
\hline \multirow{2}{*}{ 11. High tech } & 0.1147 & 0.0018 & 0.0425 \\
\hline & $(0.0810)$ & $(0.0015)$ & $(0.0300)$ \\
\hline \multirow[t]{2}{*}{ 12. Patents } & $0.0190 * *$ & $0.0003 * *$ & 0.0088 \\
\hline & $(0.0080)$ & $(0.0001)$ & $(0.0037)$ \\
\hline \multirow{2}{*}{ 13. Copyrights } & $0.0043^{* * *}$ & $0.0001 * * *$ & 0.0179 \\
\hline & $(0.0013)$ & $(0.0000)$ & $(0.0053)$ \\
\hline \multirow{2}{*}{ 14. Trademarks } & 0.0209 & 0.0003 & 0.0158 \\
\hline & $(0.0163)$ & $(0.0002$ & $(0.0124)$ \\
\hline \multirow[t]{2}{*}{ 15. Licensing out } & $1.708 * * *$ & $0.1781 * * *$ & 0.0817 \\
\hline & $(0.1220)$ & $(0.0324)$ & $(0.0063)$ \\
\hline \multirow[t]{2}{*}{ 16. Low-Knowledge IS } & 0.0806 & 0.0012 & 0.0565 \\
\hline & $(0.1025)$ & $(0.0016)$ & $(0.0718)$ \\
\hline \multirow[t]{2}{*}{ 17. High-Knowledge IS } & $0.2375^{* * *}$ & $0.0036^{* *}$ & 0.2641 \\
\hline & $(0.0883)$ & $(0.0016)$ & $(0.0986)$ \\
\hline \multirow[t]{2}{*}{ 18. Other } & 0.0032 & 0.0000 & 0.0001 \\
\hline & $(0.2933)$ & $(0.0042)$ & $(0.0083)$ \\
\hline \multirow{2}{*}{ 19. Mills Ratio } & $-3.223 * * *$ & -0.0455 & -1.2356 \\
\hline & $(0.6644)$ & $(0.0113)$ & $(0.2577)$ \\
\hline \multirow{2}{*}{ 20. Constant } & $-2.731 * * *$ & & \\
\hline & $(0.184)$ & & \\
\hline No. of Observations & 22,264 & & \\
\hline Number of groups & 4,866 & & \\
\hline Wald $\chi^{2}$ & 596.41 & & \\
\hline p-value & 0.0000 & & \\
\hline
\end{tabular}

Note: Robust standard errors in parentheses; $* * * \mathbf{p}<\mathbf{1 \%}, * * \mathbf{p}<\mathbf{5 \%}, * \mathbf{p}<\mathbf{1 0 \%}$; Estimates include regional and sector controls and fixed year effects. 


\section{Results}

From Table 2, we see that the model as a whole has good characteristics. For brevity, the main controls, years and regions, which are treated as fixed effects in our estimates, are omitted from Table 2. Full detail is given in supplementary material (Appendix B). Potential problems of sample selection bias and endogeneity have been resolved for the model, and the fit of the model (Wald $\chi^{2}$ ) is good (p-value $=0.000$ ), see last two rows in Table 2. We see that Size (first row Table 2), which is measured as headcount, is highly significant, and positive, but its marginal effect is small, as is its elasticity. However, influential as well as highly significant in Table 2 are the variables: Owners' Equity (line 6), Product (line 8) and Spend on R\&D (line 10), all with positive elasticities of $0.19,0.51$, and 0.16 , respectively. All of these elasticities imply considerable leverage on the probability of adoption of licensing-in. The significance of equity committed to the start-up, the product (rather than a service) significance, and the significance of $R \& D$ expenditure, as variables, are all indicative of the resolve of the owner manager to make a success of the start-up.

Also noteworthy is the elasticity of just over a half (0.5072) for the Product variable (line 8 in Table 2). It indicates that producing a product, rather than a service, is especially important to the adoption of licensing-in, though a shift in the Product variable would not necessarily be an easy strategy for some start-ups to achieve. All the aforementioned elasticities are positive but less than unity. Nevertheless, they do indicate material effects on the probability of licensing-in, which owner managers, and enterprise advisors alike, should take seriously. For example, a $10 \%$ increase in the spend on $\mathrm{R} \& \mathrm{D}$ will result in a roughly $2 \%$ increase in the adoption of licensing-in, and a 10\% increase in owner manager's equity would result in an additional roughly $2 \%$ increase in licensing-in adoption. Each, both, or all of these are manageable strategies for most start-ups, which collectively can have a large effect on licensing-in adoption.

We note further that, in Table 2, generally other IP types like Patents (line 12), Copyrights (line 13) and Licensing-out (line 15) also have positive effects on adoption of licensing-in. This view encourages the interpretation of start-ups seeking the best IP portfolio composition, Uzuegbunam et al. (2019), rather than just using a single method of protecting its capacity for innovation. Finally, we note the use of high knowledge information methods (see variable High Knowledge IS, last line of estimates, Table 2) is positive, highly significant and has one of the largest elasticities (0.26). We note further that the use of High Knowledge IS (38\%) (ultimate line, Table 1) is much greater than that for Low Knowledge IS (24\%) (penultimate line, Table 1). Low Knowledge IS has a very small elasticity, and is not significant in the probit anyway (see line 16, Table 2) but High Knowledge IS is highly significant (see line 17, Table 2), with a relatively large elasticity, suggesting that start-ups take advantage of its higher leverage (in terms of elasticity of response) on adoption of licensing-in. We tested the robustness of our modelling by running the estimates of our model for the economic pre-crisis (2004-2007) and post-crisis (2008-2011) subperiods. Our findings from this were largely very similar for our model e.g. in terms of the magnitudes, signs, and significance of the key variables. Slight differences were that patents were less significant during the crisis period, and $\mathrm{PhD}$ students were more significant (and positive). ${ }^{1}$

\section{Conclusions}

This article provides an econometric analysis of the determinants of licensing-in, using a large sample of US start-ups from the Kauffman Firm Survey. It models a managerial utilitymaximizing start-up, using random utility methods. This leads to a panel binary probit specification, estimated by maximum likelihood, which explains the probability of adopting

\footnotetext{
${ }^{1}$ These estimates are available from the authors on request.
} 
licensing-in by economic and financial variables, IP types and control variables. The article finds that the principal determinants of licensing-in were owner managers' equity, the selling of products (rather than services) and the expenditure on R\&D. Further, the start-up's use of high knowledge information was a significant positive determinant of licensing-in adoption. These findings are both economically insightful, as a practical demonstrations of intellectual property reasoning, as well as being useful to advisory bodies like business incubators (of which there are nearly two thousand in the USA), enterprise trusts, development companies etc. whose roles are the support of new businesses and the encouragement of more diverse means of stimulating and protecting innovations within them. This is particularly the case as Ahn et al. (2015) find that SMEs can benefit from open innovation and collaborating with external partners. To facilitate this, as suggested by Lichtenthaler (2011), they need to develop organisational capabilities to manage open innovation, particularly in evading the inefficiencies that currently exist in the markets for new technologies (Gambardella et al. 2007; Gans and Stern 2003). The rapid pace of technological change and high levels of market competition (Pereira et al. 2015; Lee et al. 2017) raise similar contemporary challenges to organizational capabilities of start-ups. To meet the policy challenge of strengthening the technological capabilities of start-up firms it is important that support agencies play a positive role in enabling new start-ups to exploit new technologies in emerging markets, see Vega-Jurado et al. (2009). Further research, building on our modelling, could examine how and why the determinants of licensing-in by start-ups vary by the type of IP acquired.

\section{Acknowledgements}

We gratefully acknowledge the excellent research assistance provided on this project by Krisztina Pákozdy.

\section{References}

Ahn, J. M., Minshall, T., \& Mortara, L. (2015). Open innovation: a new classification and its impact on firm performance in innovative SMEs. Journal of Innovation Management, 3 (2), 33-54. http://feupedicoes.fe.up.pt/journals/index.php/IJMAI/article/view/55/86

Amara N., Landry, R., and N. Traoré (2008) Managing the protection of innovations in knowledge-intensive business services, Research Policy, 37(9), 1530-1547. https://doi.org/10.1016/j.respol.2008.07.001

Anand, B.N. and Khanna, T. (2000) The structure of licensing contracts, Journal of Industrial Economics, 68(1), 103-135. https://doi.org/10.1111/1467-6451.00114

Atuahene-Gima, K. (1992) Inward technology licensing as an alternative to internal R\&D in new product development: a conceptual framework, Journal of Product Innovation Mangement, 9(2), 156-167. https://doi.org/10.1016/0737-6782(92)90007-Y

Ballou J, Barton T, DesRoches D et al. (2008) The Kauffman Firm Survey: Results from the Baseline and First Follow-Up Surveys. Available at SSRN: https://ssrn.com/abstract=1098173 (accessed $19^{\text {th }}$ June 2020).

Belingheri, P. and Leone, M.I. (2017) Walking into the room with IP: exploring start-ups' IP licensing strategy, Management Decision, 55(6),1209-1225. https://doi.org/10.1108/MD04-2016-0227.

Blank, S. and Dorf, B. (2020) The start-up owner's manual, Wiley: Hoboken, NJ, USA.

Cassiman B. and Veugelers, R. (2006) In search of complementarity in innovation strategy: internal R\&D and external knowledge acquisition, Management Science, 52(1), 68-82. https://doi.org/10.1287/mnsc. 1050.0470 
Chen M-N., and Wu C-H. (2020) Complementary-in use appropriability in innovative service firms: An empirical study in Taiwan, Research Policy 49(7), 104014. https://doi.org/10.1016/j.respol.2020.104014

Chesbrough, H. (2003) Open innovation: the new imperative for creating and profiting from technology, Harvard Business School Press: Boston, MA.

Cohen, W.M. and Levinthal, D.A. (1990) Absorptive capacity: a new perspective on learning and innovation, Administrative Science Quarterly, 35(1), 128-152. https://doi.org/10.2307/2393553

Dohse, D., Goel, R.K., and Nelson, M.A. (2019) What induces firms to license foreign technologies? International survey evidence, Managerial and Decision Economics, 40, 799814. DOI: $10.1002 /$ mde. 3044

Drechsler, W. and Natter, M. (2012) Understanding a firm's openness decisions in innovation, Journal of Business Research, 65(3), 438-445. https://doi.org/10.1016/j.jbusres.2011.11.003

Farhat, J. and Robb, A. (2018) Analyzing complex survey data: the Kauffman Firm Survey, Small Business Economics, 50(3), 657-670. https://doi.org/10.1007/s11187-017-9913-3

Gambardella, A., Giuri, P. and Luzzi, A. (2007). The market for patents in Europe. Research Policy, 36(8), 1163-1183. https://doi.org/10.1016/j.respol.2007.07.006

Gans, J.S., Hsu, D.H. and Stern, S. (2002). When Does Start-Up Innovation Spur the Gale of Creative Destruction? The RAND Journal of Economics, 33(4), 571-686. https://doi.org/10.2307/3087475

Gallié, E-P., and Legros, D., (2012) French firms' strategies for protecting their intellectual property, Research Policy, 41(4), 780-794. https://doi.org/10.1016/j.respol.2011.12.008

Greene, W.H. (2018) Econometric analysis ( $8^{\text {th }}$ edn), Pearson: London, UK.

Hausman, J.A. (1978) Specification tests in econometrics, Econometrica, 46(6), 1251-1271. https://doi.org/10.2307/1913827

Hensher, D.A. and LW Johnson, L.W. (2018) Applied discrete choice modelling, Routledge: Abingdon, Oxon, UK. https://doi.org/10.4324/9781351140768

Hung, K-P. and Chou, C. (2013) The impact of open innovation on firm performance: the moderating effects of internal $\mathrm{R} \& \mathrm{D}$ and environmental turbulence, Technovation, 33(1011), 368-380. https://doi.org/10.1016/j.technovation.2013.06.006

Hung, S-W. and Tang, R-H. (2008) Factors affecting the choice of technology acquisition mode: An empirical analysis of the electronic firms of Japan, Korea and Taiwan, Technovation, 28(9), 551-563. https://doi.org/10.1016/j.technovation.2007.10.005

$\mathrm{Hu}$, Y., McNamara, P. and McLouhglin D. (2015) Outbound open innovation in biopharmaceutical out-licensing, Technovation, 35, 46-58. https://doi.org/10.1016/j.technovation.2014.07.004

Jang, Y., Hadley, B. and Lee, W.J. (2019) Inward Technology Licensing, Financial Slack, and Internal Innovation in New Technology-Based Firms Located in Isolated Areas, The Journal of Asian Finance, Economics and Business. Korea Distribution Science Association, 6(2), 173-181. doi: 10.13106/JAFEB.2019.

Laursen, K., Leone, M.I., and Torrisi, S. (2010) Technological exploration through licensing: new insights from the licensee's point of view, Industrial and Corporate Change, 19(3), 871-897. https://doi.org/10.1093/icc/dtq034

Laursen, K., Moreira, S., Reichstein, T., Leone, M.I. (2017) Evading the boomerang effect: using the grant-back clause to further generative appropriability from technology licensing deals, Organization Science, 28(3), 514-530. https://doi.org/10.1287/orsc.2017.1130

Lichtenthaler U. (2008) Open Innovation in Practice: An Analysis of Strategic Approaches to Technology Transactions, IEEE Transactions on Engineering Management, 55(1), 148-157. doi: 10.1109/TEM.2007.912932. 
Lichtenthaler, U. (2011). Open Innovation: Past Research, Current Debates, and Future Directions, Academy of Management Perspectives, 25(1), 75-93. https://www.jstor.org/stable/23045037

Lee J.-S, Park J-H., and Bae, Z-T. (2017) The effects of licensing-in on innovative performance in different technological regimes, Research Policy, 46(2), 485-496. https://doi.org/10.1016/j.respol.2016.12.002

Lemley, M.A. (1999) Beyond pre-emption: the law and policy of intellectual property licencing, California Law Review, 87(1), 113-172. https://doi.org/10.2307/3481005

National Business Incubation Association (NBIA) (2020), http://www.nbia.org/

Parida V., Westerberg M., and Frishmmar, J. (2012) Inbound open innovation activities in hightech SMEs: the impact on innovation performance, Journal of Small Business Management, 50(2), 283-309. https://doi.org/10.1111/j.1540-627X.2012.00354.x

Pereira D., Devezas, T. and Leitão J. (2015) R\&D and licensing strategies: do they influence start-up growth? International Journal of Entrepreneurship and Small Business, 25(2), 149167._http://dx.doi.org/10.2139/ssrn.2506251

Razgaitis, R. (2003) Pricing the intellectual property of early-stage technologies: a primer of basic valuation tools and considerations, Chapter 9.3 in Dealmaking using real options and Monte-Carlo analysis, 813-860, Wiley: Hoboken, NJ, USA.

Reid, G.C. (1998) Venture capital investment: an agency analysis of practice, Routledge: London.

Robb, A. and Reedy, E.J. (2011) An overview of the Kauffman firm survey. Kauffman Foundation; Kansas City, MO.

Santoro, G., Ferraris, A., Giacosa, E., and Giovando, G. (2018) How SMEs engage in open innovation: a survey, Journal of the Knowledge Economy, 9(2), 561-574. https://doi.org/10.1007/s13132-015-0350-8

Schafer, D. (2002) In-licensing as a business model, National Biotechnology, 20, BE36-BE39. https://doi.org/10.1038/nbt0602supp-BE36

Sikimic U., Chiesa V., Frattini F., and Scalera, V. G. (2016) Investigating the influence of technology inflows on technology outflows in open innovation processes: a longitudinal analysis, Journal of Product Innovation Management, 33(6), 652-669. https://doi.org/10.1111/jpim.12319.

Spithoven A., Vanhaverbeke W. and Roijakkers, N. (2013) Open innovation practices in SMEs and large enterprises, Small Business Economics, 41(3), 537-562.

Tsai, K-H. and Chang, H-C. (2008) The contingent value of inward technology licensing on the performance of small high-technology firms, Emerging Markets Finance and Trade, 44(4), 88-98. https://doi.org/10.2753/REE1540-496X440407

Tsai, K.-H. and Wang, J.-C. (2007) Inward technology licensing and firm performance: a longitudinal study, R\&D Management, 37(2), 151-160. https://doi.org/10.1111/j.14679310.2007.00464.x

United States International Trade Commission, USITC (2020), https://www.usitc.gov/

Uzuegbunam, I., Ofem, B., and Nambisan, S. (2019) Do corporate investors affect entrepreneurs' IP portfolio? Entrepreneurial Finance and Intellectual Property in New Firms, Entrepreneurship Theory and Practice, 43(4), 673-696. https://doi.org/10.1177/1042258717738247

Vella, F. (1998) Estimating models with sample selection bias: a survey, Journal of Human Resources, 33(1), 127-169. https://doi.org/10.2307/146317

Vrande V. van de, de Jong J.P.J., Vanhaverbeke W., and de Rochemont, M. (2009) Open innovation in SMEs: Trends, motives, and management challenges, Technovation, 29(1), 423-437. https://doi.org/10.1016/j.technovation.2008.10.001 
Vega-Jurado J., Gutiérrez-Gracia A., and Fernández-de-Lucio I., (2009) Does external knowledge sourcing matter for innovation? Evidence from the Spanish manufacturing industry, Industrial and Corporate Change, 18(4), 637-670. https://doi.org/10.1093/icc/dtp023

Wang Y. and Li-Ying J. (2014) When does inward technology licensing facilitate firm's NPD performance? A contingency perspective, Technovation, 34(1), 44-53. https://doi.org/10.1016/j.technovation.2013.09.002

Zahra, S.A., Keil, T. and Maula, M. (2005) New ventures' inward licensing: examining the effects of industry and strategy characteristics. European Management Review, 2(3): 154166. https://doi.org/10.1057/palgrave.emr.1500042

\section{Appendix A. Definitions of Variables, Means and Standard Deviations.}

Table 1A. Definitions of Variables, Means and Standard Deviations.

\begin{tabular}{|c|c|c|c|c|c|c|}
\hline Variable & Definition & $\mathbf{N}$ & Mean & SD & Min & $\overline{\text { Max }}$ \\
\hline $\begin{array}{l}\text { Size } \\
\left(c 5 \_n u m \_e m p l o y e e s\right)\end{array}$ & $\begin{array}{l}\text { A count of all full-time and part-time } \\
\text { employees excluding contract workers } \\
\text { and the business owner(s) }\end{array}$ & 24,429 & 2.9367 & 6.1482 & 0 & 61 \\
\hline $\begin{array}{l}\text { Debt } \\
(\text { tot_debt_r) }\end{array}$ & $\begin{array}{l}\text { Includes total debt of the owner } \\
\text { operators and total debt of the business } \\
\text { (bank and non-bank debt sources). } \\
\text { It is captured on an ordered scale where } \\
0=\$ 0 ; 1=\text { less than } \$ 500 ; 2=\$ 501-\$ 1,000 ; \\
3=\$ 1,001-\$ 2,000 ; 4=\$ 2,000-\$ 5,000 ; \\
5=\$ 5,001 \text { to } \$ 10,000 ; 6=\$ 10,001 \text { to } \\
\$ 25,000 ; 7=\$ 25,001 \text { to } \$ 100,000 ; \\
8=\$ 100,001 \text { to } \$ 1,000,000 ; \\
\text { and } 9=\text { greater than } \$ 1,000,000 \text {. }\end{array}$ & 24,483 & 2.8857 & 3.1711 & 0 & 9 \\
\hline $\begin{array}{l}\text { Team of owners } \\
\text { (Recode of c2_owners) }\end{array}$ & $\begin{array}{l}=1 \text { if a business with more than one } \\
\text { owner; }=0 \text { otherwise }\end{array}$ & 24,660 & 0.3811 & 0.4856 & 0 & 1 \\
\hline $\begin{array}{l}\text { Purchased } \\
\text { (Recode of } \\
\text { c8_primary_loc) }\end{array}$ & $\begin{array}{l}=1 \text { if the business operates out of } \\
\text { premises which the business purchased; } \\
=0 \text { otherwise }\end{array}$ & 24,650 & 0.0643 & 0.2453 & 0 & 1 \\
\hline $\begin{array}{l}\text { Incorporated } \\
\text { (Recode of } \\
\text { c1z_confirm_legal_status) }\end{array}$ & $\begin{array}{l}=1 \text { if the business is incorporated } ;=0 \\
\text { otherwise }\end{array}$ & 24,650 & 0.6475 & 0.4777 & 0 & 1 \\
\hline $\begin{array}{l}\text { Total equity of owners } \\
\text { (tot_equity_owner_operato } \\
\left.r s \_r\right)\end{array}$ & $\begin{array}{l}\text { Includes total equity of the owner } \\
\text { operators. It is captured on an ordered } \\
\text { scale where } 0=\$ 0 ; 1=\text { less than } \$ 500 ; \\
2=\$ 501-\$ 1,000 ; 3=\$ 1,001-\$ 2,000 ; \\
4=\$ 2,000-\$ 5,000 ; 5=\$ 5,001 \text { to } \$ 10,000 ; \\
6=\$ 10,001 \text { to } \$ 25,000 ; 7=\$ 25,001 \text { to } \\
\$ 100,000 ; 8=\$ 100,001 \text { to } \$ 1,000,000 ; \\
\text { and } 9=\text { greater than } \$ 1,000,000 \text {. }\end{array}$ & 24,387 & 2.1494 & 2.8010 & 0 & 9 \\
\hline $\begin{array}{l}\text { Service } \\
\text { (dla_provide_service) }\end{array}$ & $\begin{array}{l}=1 \text { if a business sells a service } ;=0 \\
\text { otherwise }\end{array}$ & 24,570 & 0.8610 & 0.3459 & 0 & 1 \\
\hline $\begin{array}{l}\text { Product } \\
\text { (d1b_provide_product) }\end{array}$ & $\begin{array}{l}=1 \text { if a business sells a product } ;=0 \\
\text { otherwise }\end{array}$ & 24,567 & 0.4861 & 0.4998 & 0 & 1 \\
\hline $\begin{array}{l}\text { PhD } \\
\text { (Recode of } \\
\text { g9_education_owner) }\end{array}$ & Count of owners with PhD degree & 25,542 & 0.0945 & 0.3608 & 0 & 6 \\
\hline $\begin{array}{l}\text { Expenditure on } \mathrm{R} \& \mathrm{D} \\
(\text { f19_res_dev })\end{array}$ & $\begin{array}{l}=1 \text { if the business spent money on } \\
\text { research and development of new } \\
\text { products and services during calendar; = } \\
0 \text { otherwise. }\end{array}$ & 24,343 & 0.1890 & 0.3915 & 0 & 1 \\
\hline
\end{tabular}




\begin{tabular}{|c|c|c|c|c|c|c|}
\hline $\begin{array}{l}\text { High tech } \\
\text { (hightech) }\end{array}$ & $\begin{array}{l}=1 \text { if } 28 \text { Chemicals and allied products, } \\
35 \text { Industrial machinery and equipment, } \\
36 \text { Electrical and electronic equipment or } \\
38 \text { Instruments and related products; } \\
=0 \text { otherwise }\end{array}$ & 25,542 & 0.1281 & 0.3342 & 0 & 1 \\
\hline $\begin{array}{l}\text { Patents } \\
\text { (total_patents) }\end{array}$ & Count of patents of the business & 24,335 & 0.1717 & 1.9919 & 0 & 100 \\
\hline $\begin{array}{l}\text { Copyrights } \\
\text { (total_copyrights) }\end{array}$ & Count of copyrights of the business & 24,058 & 1.4881 & 12.2427 & 0 & 250 \\
\hline $\begin{array}{l}\text { Trademarks } \\
\text { (total_trademarks) }\end{array}$ & $\begin{array}{l}\text { Count of registered trademarks of the } \\
\text { business }\end{array}$ & 23,987 & 0.2809 & 1.4617 & 0 & 100 \\
\hline $\begin{array}{l}\text { Out-licensing } \\
\text { (Recode of d4_a_lic_out_paten } \\
\text { d4_b_lic_out_copyright and } \\
\text { d4_c_lic_out_trademark) }\end{array}$ & ent $=1$ out-licensing; $=0$ otherwise & 25,542 & 0.0039 & 0.0642 & 0 & 1 \\
\hline $\begin{array}{l}\text { Licensing -in } \\
\text { (Recode of d5_a_lic_in_patent } \\
\text { d5_b_lic_in_copyright and } \\
\text { d5_c_lic_in_trademark) }\end{array}$ & $=1$ licensing-in $;=0$ otherwise & 24,310 & 0.0573 & 0.2323 & 0 & 1 \\
\hline $\begin{array}{l}\text { Manufacturing (reference) } \\
\text { (Recode of naics_code) }\end{array}$ & $=1$ Manufacturing $;=0$ otherwise & 25,513 & 0.1444 & 0.3415 & 0 & 1 \\
\hline $\begin{array}{l}\text { Construction } \\
\text { (Recode of naics_code) }\end{array}$ & $=1$ Construction $;=0$ otherwise & 25,513 & 0.0796 & 0.2707 & 0 & 1 \\
\hline $\begin{array}{l}\text { Wholesale Retail } \\
\text { (Recode of naics_code) }\end{array}$ & $=1$ Wholesale and Retail; $=0$ otherwise & 25,513 & 0.1436 & 0.3507 & 0 & 1 \\
\hline $\begin{array}{l}\text { Low Knowledge IS } \\
\text { (Recode of naics_code) }\end{array}$ & $=1$ Low KIS $;=0$ otherwise & 25,513 & 0.2383 & 0.4261 & 0 & 1 \\
\hline $\begin{array}{l}\text { Knowledge IS } \\
\text { (Recode of naics_code) }\end{array}$ & $\begin{array}{l}=1 \text { Knowledge Intensive Services }=0 \\
\text { otherwise }\end{array}$ & 25,513 & 0.3828 & 0.4861 & 0 & 1 \\
\hline $\begin{array}{l}\text { Other } \\
\text { (Recode of naics_code) }\end{array}$ & $=1$ Other $;=0$ otherwise & 25,513 & 0.0113 & 0.1058 & 0 & 1 \\
\hline $\begin{array}{l}\text { Year } 2004 \text { (reference) } \\
\text { (year) }\end{array}$ & $=12004 ;=0$ otherwise & 25,542 & 0.1928 & 0.3945 & 0 & 1 \\
\hline $\begin{array}{l}\text { Year } 2005 \\
\text { (year) }\end{array}$ & $=12005 ;=0$ otherwise & 25,542 & 0.1593 & 0.3659 & 0 & 1 \\
\hline $\begin{array}{l}\text { Year } 2006 \\
\text { (year) }\end{array}$ & $=12006 ;=0$ otherwise & 25,542 & 0.1407 & 0.3479 & 0 & 1 \\
\hline $\begin{array}{l}\text { Year } 2007 \\
\text { (year) }\end{array}$ & $=12007 ;=0$ otherwise & 25,542 & 0.1254 & 0.3312 & 0 & 1 \\
\hline $\begin{array}{l}\text { Year } 2008 \\
\text { (year) }\end{array}$ & $=12008 ;=0$ otherwise & 25,542 & 0.1100 & 0.3130 & 0 & 1 \\
\hline $\begin{array}{l}\text { Year } 2009 \\
\text { (year) }\end{array}$ & $=12009 ;=0$ otherwise & 25,542 & 0.1014 & 0.3019 & 0 & 1 \\
\hline $\begin{array}{l}\text { Year } 2010 \\
\text { (year) }\end{array}$ & $=12010 ;=0$ otherwise & 25,542 & 0.0900 & 0.2863 & 0 & 1 \\
\hline $\begin{array}{l}\text { Year } 2011 \\
\text { (year) }\end{array}$ & $=12011 ;=0$ otherwise & 25,542 & 0.0801 & 0.2175 & 0 & 1 \\
\hline $\begin{array}{l}\text { North East (reference) } \\
\text { (Recode of census_region) }\end{array}$ & $=1$ North East $;=0$ otherwise & 24,369 & 0.1618 & 0.4377 & 0 & 1 \\
\hline $\begin{array}{l}\text { Mid-West } \\
\text { (Recode of census_region) }\end{array}$ & $=1$ Mid-West $;=0$ otherwise & 24,369 & 0.2566 & 0.4367 & 0 & 1 \\
\hline $\begin{array}{l}\text { South } \\
\text { (Recode of census_region) }\end{array}$ & $=1$ South $;=0$ otherwise & 24,369 & 0.3228 & 0.4680 & 0 & 1 \\
\hline $\begin{array}{l}\text { West } \\
\text { (Recode of census_region) }\end{array}$ & $=1$ West $;=0$ otherwise & 24,369 & 0.2588 & 0.4380 & 0 & 1 \\
\hline
\end{tabular}

Note: Data source is the Kauffmann data https://www.kauffman.org/entrepreneurship/research/kauffman-firm-surv. 


\section{Appendix B. Panel Probit ML Estimates.}

Table 2A. Panel Probit ML Estimates.

\begin{tabular}{|c|c|c|c|}
\hline Variables & $\begin{array}{r}\text { Parameters } \beta \\
\text { (Standard error) } \\
\end{array}$ & $\begin{array}{r}\text { Marginal effects } \mathrm{dy} / \mathrm{dx} \\
\text { (Standard error) }\end{array}$ & $\begin{array}{r}\text { Ey/Ex } \\
\text { Elasticities } \\
\end{array}$ \\
\hline \multirow[t]{2}{*}{ 1. Size } & $0.0118 * * *$ & $0.0002 * * *$ & 0.0974 \\
\hline & $(0.0041)$ & $(0.0001)$ & $(0.0342)$ \\
\hline \multirow[t]{2}{*}{ 2. Debt } & 0.0104 & 0.0001 & 0.0872 \\
\hline & $(0.0082)$ & $(0.0001)$ & $(0.0688)$ \\
\hline \multirow[t]{2}{*}{ 3. Team of Owners } & $0.1167 *$ & $0.0017^{*}$ & 0.1284 \\
\hline & $(0.0657)$ & $(0.0010)$ & $(0.0726)$ \\
\hline \multirow[t]{2}{*}{ 4. Purchased } & -0.1834 & $-0.0021 *$ & -0.0345 \\
\hline & $(0.1279)$ & $(0.0010)$ & $(0.0240)$ \\
\hline \multirow[t]{2}{*}{ 5. Incorporated } & 0.1011 & 0.0014 & 0.1894 \\
\hline & 0.0711 & $(0.0010)$ & $(0.1334)$ \\
\hline \multirow[t]{2}{*}{ 6. Owners' Equity } & $0.0310 * * *$ & $0.0004 * * *$ & 0.1915 \\
\hline & $(0.0084)$ & $(0.0001)$ & $(0.0525)$ \\
\hline \multirow[t]{2}{*}{ 7. Service } & 0.0013 & 0.0000 & 0.0031 \\
\hline & $(0.0811)$ & $(0.0011)$ & $(0.2033)$ \\
\hline \multirow[t]{2}{*}{ 8. Product } & $0.3664 * * *$ & $0.0055^{* * *}$ & 0.5072 \\
\hline & $(0.0588)$ & $(0.0012)$ & $(0.0830)$ \\
\hline \multirow[t]{2}{*}{ 9. $P h D$} & 0.0972 & 0.0014 & 0.0270 \\
\hline & $(0.0688)$ & $(0.0010)$ & $(0.0192)$ \\
\hline \multirow[t]{2}{*}{ 10. Spend on $R \& D$} & $0.3072 * * *$ & $0.0057 * * *$ & 0.1614 \\
\hline & $(0.0583)$ & $(0.0016)$ & $(0.0309)$ \\
\hline \multirow[t]{2}{*}{ 11. High tech } & 0.1147 & 0.0018 & 0.0425 \\
\hline & $(0.0810)$ & $(0.0015)$ & $(0.0300)$ \\
\hline \multirow[t]{2}{*}{ 12. Patents } & $0.0190 * *$ & $0.0003 * *$ & 0.0088 \\
\hline & $(0.0080)$ & $(0.0001)$ & $(0.0037)$ \\
\hline \multirow[t]{2}{*}{ 13. Copyrights } & $0.0043 * * *$ & $0.0001 * * *$ & 0.0179 \\
\hline & $(0.0013)$ & $(0.0000)$ & $(0.0053)$ \\
\hline \multirow[t]{2}{*}{ 14. Trademarks } & 0.0209 & 0.0003 & 0.0158 \\
\hline & $(0.0163)$ & $(0.0002$ & $(0.0124)$ \\
\hline \multirow[t]{2}{*}{ 15. Licensing out } & $1.708 * * *$ & $0.1781 * * *$ & 0.0817 \\
\hline & $(0.1220)$ & $(0.0324)$ & $(0.0063)$ \\
\hline \multirow[t]{2}{*}{ 16. Low-Knowledge IS } & 0.0806 & 0.0012 & 0.0565 \\
\hline & $(0.1025)$ & $(0.0016)$ & $(0.0718)$ \\
\hline \multirow{2}{*}{$\begin{array}{l}\text { 17. High-Knowledge } \\
\text { IS }\end{array}$} & $0.2375 * * *$ & $0.0036^{* *}$ & 0.2641 \\
\hline & $(0.0883)$ & $(0.0016)$ & $(0.0986)$ \\
\hline \multirow[t]{2}{*}{ 18.Construction } & $-0.3085^{* *}$ & $-0.0032 * * *$ & -0.0712 \\
\hline & $(0.1472)$ & $(0.0011)$ & $(0.0341)$ \\
\hline \multirow[t]{2}{*}{ 19.Wholesale Retail } & -0.0264 & -0.0004 & -0.0110 \\
\hline & $(0.1028)$ & $(0.0014)$ & $(0.0429)$ \\
\hline \multirow[t]{2}{*}{ 20. Other } & 0.0032 & 0.0000 & 0.0001 \\
\hline & $(0.2933)$ & $(0.0042)$ & $(0.0083)$ \\
\hline \multirow[t]{2}{*}{ 21. West } & 0.0737 & 0.0011 & 0.0558 \\
\hline & $(0.0969)$ & $(0.0015)$ & $(0.0734)$ \\
\hline \multirow[t]{2}{*}{ 22. South } & 0.1158 & 0.0017 & 0.1093 \\
\hline & $(0.0932)$ & $(0.0015)$ & $(0.0880)$ \\
\hline \multirow[t]{2}{*}{ 23. Mid-West } & 0.1384 & 0.0021 & 0.1021 \\
\hline & $(0.0948)$ & $(0.0016)$ & $(0.0700)$ \\
\hline 24. Year 2005 & $-0.1166^{*}$ & $-0.0015^{*}$ & -0.0552 \\
\hline & $(0.0638)$ & $(0.0008)$ & $(0.0302)$ \\
\hline
\end{tabular}




\begin{tabular}{lrrr}
\hline 25. Year 2006 & -0.1128 & $-0.0014^{*}$ & -0.0449 \\
26. Year 2007 & $(0.0704)$ & $(0.0008)$ & $(0.0280)$ \\
27. Year 2008 & -0.0793 & -0.0010 & -0.0264 \\
& $(0.0756)$ & $(0.0009)$ & $(0.0251)$ \\
28. Year 2009 & $-0.1584^{* *}$ & $-0.0019^{* *}$ & -0.0499 \\
29. Year 2010 & $(0.0796)$ & $(0.0009)$ & $(0.0251)$ \\
& $-0.1769^{* *}$ & $-0.0021^{* *}$ & -0.0512 \\
30. Year 2011 & $(0.0837)$ & $(0.0009)$ & $-0.0243)$ \\
& $-0.2706^{* * *}$ & $-0.0029^{* * *}$ & -0.0700 \\
31. Mills Ratio & $(0.0920)$ & $-0.00031^{* * *}$ & -0.0740 \\
32. Constant & $-0.3030^{* * *}$ & $(0.0008)$ & $(0.0230)$ \\
& $(0.0969)$ & $-0.0455^{* * *}$ & -1.2356 \\
No. of Observations & $-3.223^{* * *}$ & $(0.0113)$ & $(0.2577)$ \\
Number of groups & $(0.6644)$ & & \\
Wald $\chi^{2}$ & $-2.731^{* * *}$ & & \\
p-value & $(0.184)$ & & \\
\hline \hline
\end{tabular}

Note: Robust standard errors in parentheses; $* * * p<1 \%, * * p<5 \%,{ }^{*} p<10 \%$. 